\title{
Pengaruh Implementasi Corporate Governance terhadap Efisiensi Bank Umum di Indonesia
}

\author{
Eliana $^{1)}$, Dian Wahyuni ${ }^{2)}$ \\ ${ }^{12)}$ Prodi Akuntansi, Sekolah Tinggi Ilmu Ekonomi Sabang, Banda Aceh \\ Jalan Prada Utama No. 15, Peurada, Syiah Kuala, Banda Aceh \\ Email:eliana@stiesabang.ac.id ${ }^{1)}$,dhian@stiesabang.ac.id ${ }^{2)}$
}

\begin{abstract}
The implementation of good corporate governance $(G C G)$ is an important thing in sustaining the operational activities of banking companies. This thing is due to the company requires good governance so that, all operational activities can be carried out by transparent, accountable, and efficient. Studies on the relationship between the application of GCG dimensions and company efficiency have been carried out by researchers. However, in the context of bank financial services companies, the functional relationship between the efficiency of the company and the implementation of GCG dimension has not been widely disclosed by the researcher. Even if any, the results of the research they have found were still paradoxical from one another. This study aims to analyze the effect of the implementation of GCG on the efficiency of commercial banks in Indonesia. The GCG implementation is limited to four dimensions consisting of share ownership, the board size, board composition, and separation of CEO and board. The research sample consisted of 20 banking companies listed on the IDX from 2013 to 2018. Data collection through documentation of the financial statements of each bank. Furthermore, the data analyzed using the econometric model of the fixed-effect methods panel regression. The study found that simultaneously the four dimensions of GCG had a significant effect on the efficiency of banking companies. Partially the concentration of share ownership negatively affects efficiency. In contrast, the composition of the board and the separation between the CEO and the board have a positive effect. Furthermore, board size does not affect the efficiency of the banking company.
\end{abstract}

Keywords : Efficiency of Banking, The implementation of GCG and Panel Regression

\begin{abstract}
ABSTRAK
Penerapan tata kelola perusahaan yang baik merupakan hal penting dalam menopang kegiatan operasional perusahaan perbankan. Hal ini disebabkan karena perusahaan membutuhkan tata kelola yang baik sehingga, semua kegiatan operasional dapat dilakukan secara transparan, akuntabel, dan efisien. Studi tentang hubungan antara penerapan dimensi GCG dan efisiensi perusahaan telah dilakukan oleh para peneliti. Namun, dalam konteks perusahaan jasa keuangan bank, hubungan fungsional antara efisiensi perusahaan dan penerapan dimensi GCG belum diungkapkan secara luas oleh peneliti. Bahkan jika ada, hasil penelitian yang mereka temukan masih bertentangan satu sama lain. Penelitian ini bertujuan untuk menganalisis pengaruh implementasi GCG terhadap efisiensi bank umum di Indonesia. Implementasi GCG yang dimaksudkan dibatasi hanya pada empat dimensi terdiri dari kepemilikan saham, ukuran komisaris, komposisi komisaris dan pemisahan CEO dan komisaris. Sampel penelitian sebanyak 20 perusahaan perbankan yang listing di BEI selama periode 2013-2018. Pengumpulan data dilakukan melalui dokumentasi terhadap laporan keuangan masing-masing bank. Selanjutnya data dianalisis dengan menggunakan peralatan ekonometrik regresi panel metode fixed effect model. Penelitian menemukan bahwa secara simultan keempat dimensi GCG tersebut berpengaruh signifikan terhadap efisiensi perusahaan perbankan. Secara parsial konsentrasi kepemilikan saham oleh pihak internal perusahaan berpengaruh negatif terhadap efisiensi. Sebaliknya, komposisi komisaris dan pemisahan antara CEO dan komisaris berpengaruh positif. Selanjutnya ukuran komisaris tidak berpengaruh terhadap efisiensi perusahaan perbankan.
\end{abstract}

Kata kunci : Efisiensi Perusahaan, Implementasi GCG dan Regresi Panel 


\section{Pendahuluan}

Efisiensi pengelolaan kegiatan operasional menjadi syarat penting dalam upaya peningkatan pendapatan bagi setiap perusahaan, termasuk perusahaan jasa keuangan bank. Apalagi bank memiliki peran penting dalam menjalankan fungsi intermediasi keuangan di masyarakat (Amri, 2018). Terjadinya penurunan efisiensi tidak hanya berpengaruh kemampuan bank dalam menjalankan fungsi tersebut, tetapi juga berdampak pada sejumlah variabel makro ekonomi seperti pertumbuhan ekonomi dan ketimpangan pendapatan (Amri \& Nazamuddin, 2018).

Pentingnya efisiensi dalam perusahaan jasa perbankan tidak hanya perlu menjadi perhatian pihak manajemen, tetapi juga menjadi pertimbangan penting bagi pemilik perusahaan yang dalam hal ini adalah pemegang saham. Untuk mewujudkan efisiensi pengelolaan lembaga keuangan diperlukan adanya tata pengelolaan perusahaan yang baik (good corporate governance, GCG). Prinsip dasar GCG yaitu transparansi, akuntabilitas, responbiitas, independensi, serta kewajaran dan kesetaraan (fairness) diperlukan untuk mencapai kesinambungan usaha (sustainability) dengan memperhatikan pemangku kepentingan (stakeholders).

Perusahaan jasa perbankan yang terdaftar di Bursa Efek Indonesia (BEI) membutuhkan sistem pengelolaan yang baik yang dapat digunakan untuk mencapai tujuan perusahaan meliputi penentuan strategi dan kebijakan, baik dalam hal finansial maupun non finansial. Dalam sistem pengelolaan perusahaan yang baik, dewan direksi dan komisaris memiliki peranan yang penting. Tata kelola perusahaan yang baik akan memberikan dorongan kepada dewan dan manajemen untuk mencapai tujuan perusahaan, yang merupakan kepentingan perusahaan dan para pemegang sahamnya.

Di antara beberapa indikator $G C G$ terkait dengan proporsi kepemilikan saham, ukuran/jumlah komisaris, komposisi komisaris, dan pemisahan struktur kepemimpinan. Keterkaitan antara proporsi kepemilikan saham dengan efisiensi perusahaan disebabkan secara umum pemegang saham memiliki kepentingan dengan efisiensi perusahaan. Ketika sebagian besar saham perusahaan dimiliki oleh pihak internal, maka upaya untuk meningkatkan efisiensi perusahaan menjadi kepentingan internal perusahaan. Sehingga semakin besar porsi kepemilikan saham oleh pihak internal perusahaan akan mendorong manajemen untuk meningkatkan efisiensi perusahaan.

Ukuran komisaris (board size) juga dapat berpengaruh pada efisiensi. Beberapa peneliti sebelumnya merekomendasikan jumlah komisaris yang optimal mungkin dapat mengurangi pengaruh manajemen terhadap keputusan. Temuan penelitian Dalton et al. (2006) menyatakan terdapat hubungan negatif antara board size dengan efisiensi dan kinerja perusahaan. Ukuran komisaris yang relatif besar berimplikasi bahwa pengeluaran perusahaan dalam bentuk gaji komisaris juga meningkat. Hal inilah yang menyebabkan ukuran komisaris berkorelasi negatif dengan efisiensi perusahaan.

Selanjutnya komposisi komisaris (board composition) juga dapat berdampak pada efisiensi perusahaan. Komposisi komisaris yang dimaksudkan disini adalah adanya komisaris independen. Semakin besar proporsi komisaris independen berarti semakin baik komposisi komisaris. Krivogorsky (2006) dan Rebeiz and Salameh (2006) menyatakan pentingnya direkur independen. Mereka menemukan bahwa terhadap hubungan positif antara efisiensi bank dengan proporsi non-executive director yang independen.

Selanjutnya implementasi GCG juga diwujudkan dalam bentuk pemisahan antara CEO dan komisaris. Teori keagenan dan ketentuan GCG menekankan pentingnya komisaris independent dari manajemen melalui pemisahan antara chief excecutive official (CEO) dengan komisaris. Penelitian Rebeiz dan Salameh (2006) menemukan bahwa pemisahan antara chief excecutive official (CEO) dengan komisaris memiliki hubungan positif dengan efisiensi perusahaan.

Efisiensi operasional perusahaan jasa perbankan yang terdaftar di BEI tentunya juga dapat dikaitkan dengan penerapan prinsip $G C G$ seperti dijelaskan di atas, yakni proporsi kepemilikan saham, jumlah komisaris dalam perusahaan, komposisi dewan komisaris dan pemisahan antara jajaran direksi atau chief executive official dan komisaris.

Hasil pengumpulan data awal menunjukkan bahwa masing-masing perusahaan jasa keuangan bank yang terdaftar di BEI memiliki tingkat efisiensi yang berbeda satu sama lain. Efisiensi yang dimaksudkan dalam hal ini diukur dari perbandingan antara biaya operasional dengan pendapatan operasional (BOPO). Sebagian perusahaan memiliki rasio BOPO relatif lebih besar dan hal ini mengindikasikan tingkat efisiensi yang rendah. Sebaliknya terdapat sejumlah perusahaan dengan rasio BOPO relatif rendah. Perusahaan ini dapat dikatakan memiliki tingkat efisiensi relatif lebih baik dibandingkan dengan kelompok pertama.

Selain itu, penerapan $G C G$ pada masing-masing perusahaan juga relatif berbeda, baik dilihat dari segi proporsi kepemilikan saham, jumlah komisaris dalam perusahaan, komposisi dewan komisaris, maupun pemisahan antara jajaran direksi atau chief executive official dan komisaris. Karena itu penelitian ini bertujuan untuk menganalisis efisiensi perusahaan jasa perbankan yang terdaftar di BEI dengan menggunakan empat variabel tersebut sebagai predictor variable.

\section{A. Literatur Review}

1. Efisiensi Bank Umum

Efisiensi lembaga keuangan dapat dibedakan menjadi 2 jenis yaitu efisiensi operasi untuk mengukur efisiensi operasional dan X-efficiency untuk menjelaskan perbedaan efisiensi antar bank (Ceha, 2000). Konsep efisiensi operasi adalah murni teknis dan dapat didefinisikan sebagai efisiensi teknis produksi yang menunjukkan seberapa jauh proses produksi lembaga keuangan tersebut dari isoquan. Sementara efisiensi 
alokatif menggambarkan in-efisiensi berhubungan dengan kenyataan ketika lembaga keuangan tersebut menggunakan kombinasi input yang tidak optimal pada harga input tertentu (Laeven,, 2009).

Dalam perusahaan perbankan, pengukuran efisiensi dapat dilakukan dengan menggunakan rasio biaya operasi dan pendapatan operasi (BOPO). Rasio ini merupakan ukuran efisiensi yang lazim dipakai untuk memberikan penilaian atas kinerja efisiensi bank (Wijayanto, 2010). Dalam dunia perbankan di Indonesia, rasio biaya operasional dan pendapatan operasional (BOPO) merupakan ukuran efisiensi yang sering dipakai untuk memberikan penilaian atas kinerja efisiensi bank Rasio BOPO didapat dari perbandingan antara biaya operasional dengan pendapatan operasional, rasio ini digunakan karena adanya kemudahan dalam perhitungan dan penggunaan.

\section{Mekanisme dan Implementasi Corporate Governance}

Sistem $G C G$ pada perusahaan modern dibagi menjadi dua bagian yaitu mekanisme internal governance dan mekanisme external governance yang sifatnya beragam tergantung lingkungan tertentu yang dianjurkan (Weir et al., 2000). Indikator mekanisme internal governance terdiri dari jumlah dewan direktur, proporsi dewan komisaris independen dan debt to equity sedangkan indikator mekanisme external governance terdiri dari institutional ownership (Beiner et al., 2003). Dengan berjalannya kedua mekanisme tersebut secara bersamaan, maka sistem corporate governance perusahaan mencoba memotivasi manajer agar memaksimalkan nilai pemegang saham.

Implementasi corporate governance dalam penelitian ini dibatasi hanya struktur kepemilikan, ukuran komisaris, komposisi komisaris dan pemisahan antara chief executive official dan komisaris (separate leadership structure). Masing-masing konsep tersebut dijelaskan sebagai berikut.

\section{Keterkaitan Implementasi Good Corporate} Governance dan Efisiensi

a. Proporsi kepemilikan saham dan efisiensi bank umum

Struktur kepemilikan merupakan salah satu penentu utama pelaksanaan $G C G$ dalam perusahaan. Pola kepemilikan dan jenis kepemilikan mempengaruhi struktur kepemilikan dari perusahaan. Berdasarkan pola kepemilikannya, perusahaan dapat dibedakan menjadi 2 yaitu perusahaan terkonsentrasi dan menyebar, sedangkan jenis kepemilikan perusahaan mencakup kepemilikan pemerintah, kepemilikan manajerial dan kepemilikan institusional.

Bukti empiris mengenai keterkaitan antara konsentrasi kepemilikan dan efisiensi perusahaan jasa perbankan masih memberikan hasil yang paradoks. Beberapa penelitian sebelumnya menyimpulkan adanya hubungan positif antara konsentrasi kepemilikan saham dengan efisiensi perusahaan (Perrini et al., 2008; Silva \& Majluf, 2008; Garcia-Meca \& Sa'nchez-Ballesta, 2011).
Mereka berargumen bahwa semakin besar konsentrasi kepemilikan dapat mengurangi konflik keagenan antara pemilik dan manajemen dan mengurangi biaya pengawasan manajemen sehingga mendorong efisiensi. Sebaliknya temuan lain memperlihatkan terdapat hubungan negatif antara konsentasi kepemilikan dan efisiensi perusahaan (Boone et al., 2011 dan Jiang et al., 2009).

b. Ukuran Komisaris dan Efisiensi Bank Umum

Ukuran komisaris (board size) digunakan sebagai indikasi peran pengawasan dan monitoring (Klein, 2008), sehingga memiliki peran penting bagi kesuksesan dan pertumbuhan perusahaan. Tanggung jawab utama dewan komisaris adalah untuk melindungi aset pemegang saham dan memastikan mereka menerima return atas investasi mereka. Adam dan Mehran (2003) menyatakan, ketika perusahaan memiliki dewan komisaris relatif banyak, akan terdapat cukup orang untuk memonitor kegiatan manajemen secara efektif, dan hal tersebut sehingga berdampak baik pada efisiensi kegiatan operasional perusahaan.

Adanya keterkaitan antara ukuran/jumlah komisaris dengan efisiensi perusahaan dibuktikan dalam penelitian Adnan et al. (2011) bahwa ukuran/jumlah komisaris berpengaruh positif dan signifikan terhadap efisiensi perusahaan jasa perbankan.

c. Komposisi Komisaris dan Efisiensi Bank Umum

Choe dan Lee (2003) menyatakan bahwa komposisi komisaris penting untuk memonitor manajer agar dapat mengurangi biaya keagenan. Walaupun direktur eksekutif memiliki keahlian dan pengetahuan yang baik untuk menjalankan kebijakan operasi dan aktivitas perusahaan sehari-hari, ada kebutuhan akan direktur independen untuk memberikan ide, independensi, objektivitas dan keahlian sesuai dengan bidang keahlian mereka. Penelitian yang dilakukan oleh Bozec \& Dia (2005), Krivogorsky (2006) dan Rebeiz dan Salameh (2006) menyoroti pentingnya direktur independen.

Adanya keterkaitan antara board composition dengan efisiensi perusahaan jasa keuangan bank seperti dikemukakan oleh Tanna et al. (2011) yang menyatakan bahwa board composition memiliki dampak positif dan signifikan terhadap efisiensi. Pendapat berbeda dikemukakan oleh Bebeji et al. (2015) yang menyatakan bahwa board composition justru mendorong penurunan ROE dan ROA.

d. Pemisahan antara CEO dan Komisaris, dan efisiensi bank umum

Adanya pemisahan antara CEO dan komisaris dapat berpengaruh terhadap efisiensi perusahaan jasa perbankan. Hal ini dikemukakan oleh Ehikioya \& Benjami (2009) bahwa CEO dan dewan komisaris dipisahkan untuk memastikan kemampuan perusahaan dalam meningkatkan modal tambahan dan mengurangi kesempatan terjadinya korupsi pada perusahaan. Namun beberapa peneliti setujuh bahwa tidak ada struktur kepemimpinan yang optimal karena perspektif pemisahan dan dualitas tersebut berhubungan dengan cost dan benefit. 
Sesuai dengan latar belakang penelitian yang telah dikemukakan bahwa $G C G$ yang dimaksudkan dalam penelitian ini dipresentasikan oleh empat variabel yakni proporsi kepemilikan saham, ukuran komisaris, komposisi komisaris dan pemisahan struktur kepemimpinan. Keempat variabel tersebut digunakan untuk memprediksi efisiensi perusahaan jasa perbankan yang terdaftar di BEI. Adanya keterkaitan antara keempat variabel dengan efisiensi perusahaan jasa perbankan tidak hanya dijelaskan secara teoritis, tetapi juga didukung oleh penelitian empiris sebelumnya. Sehingga hubungan antara variabel atau kerangka pemikiran penelitian ini seperti ditunjukkan dalam Gambar 1.

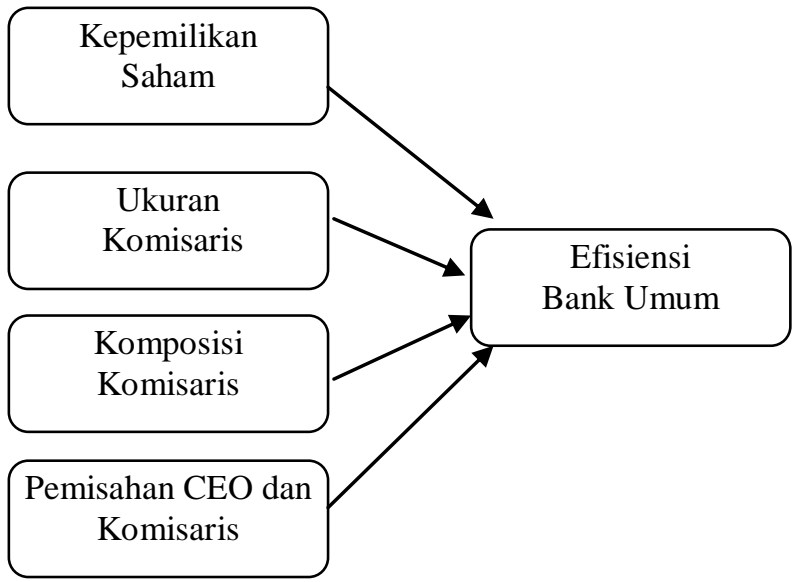

Gambar 1. Kerangka Pemikirian Penelitian

\section{B. Metode Penelitian}

Pada penelitian ini yang menjadi populasi adalah seluruh Bank Umum yang listing di Bursa Efek Indonesia hingga periode tahun 2018. Sampel penelitian dibatasi pada 20 emiten perusahaan jasa perbankan yang mempublikasikan keuangannya selama periode tahun 2013-2017 dan memiliki komisaris independen. Data yang digunakan dalam penelitian ini adalah data primer yang diambil secara langsung dari laporan keuangan dan laporan tahunan perusahaan jasa perbankan yang dijadikan sampel penelitian. Pengumpulan data dilakukan dengan cara mendokumentasikan dokumendokumen terkait yang dapat diperoleh secara online melalui internet.

Secara detail, variabel yang dioperasionalkan dalam penelitian ini dapat dikelompokkan dalam dua kelompok, yakni variabel dependen dan variabel independen.

Variabel dependen atau disebut juga dengan variabel terikat dalam penelitian ini adalah efisiensi perusahaan jasa perbankan yang diukur dengan menggunakan rasio biaya operasi terhadap pendapatan operasi. Semakin besar rasio BOPO berarti efisiensi menurun, sebaliknya semakin kecil rasio BOPO berarti efisiensi meningkat.

Selanjutnya variabel independen terdiri dari:

a. Proporsi kepemilikan saham oleh institusi/perusahaan. Variabel ini didasarkan pada rasio jumlah saham yang dimiliki oleh internal perusahaan dengan jumlah total saham secara keseluruhan. b. Ukuran komisaris, adalah jumlah komisaris dalam perusahaan dihitungan dengan satuan orang.

c. Komposisi komisaris, indikator yang digunakan untuk mengukur variabel ini adalah rasio komisaris independen terhadap total komisaris yang kemudian dinyatakan dalam bentuk persen.

d. Adanya pemisahan antara CEO dan komisaris. Variabel ini diukur dengan dummy variabel dengan ketentuan: 1 = terdapat pemisahan antara CEO dan komisaris, dan $0=$ tidak terdapat pemisahan antara $\mathrm{CEO}$ dan komisaris.

Peralatan analisis data yang digunakan menganalisis memprediksi pengaruh keempat prinsip $G C G$ (seperti dijelaskan di atas) terhadap efisiensi perusahaan perbankan adalah regresi panel dengan menggunakan dumy variable. Penggunaan variabel dumy disebabkan terdapat salah satu prinsip GCG yang diukur dengan menggunakan skala katagori seperti halnya pemisahan antara CEO dan komisaris. Secara ekonometrik, regresi panel tersebut diformulasikan sebagai berikut:

$\mathrm{BOPO}_{\text {it }}=\mathrm{a}+\mathrm{b}_{1} \mathrm{KS}_{\mathrm{it}}+\mathrm{b}_{2} \mathrm{UK}_{\mathrm{it}}+\mathrm{b}_{3} \mathrm{KK}_{\mathrm{it}}+\mathrm{b}_{4} \mathrm{PCEO}_{\mathrm{it}}$

Dimana:

BOPO $_{\text {it }}$ : Rasio biaya operasi terhadap pendapatan operasi pada emiten $i$ dalam periode $t$.

$\mathrm{KS}_{\mathrm{it}} \quad$ : Kepemilikan saham pada emiten $i$ dalam periode $t$

$\mathrm{UK}_{\mathrm{it}}$ : Ukuran komisaris pada emiten $i$ dalam periode $t$.

$\mathrm{KK}_{\mathrm{it}}$ : Komposisi komisaris pada emiten $i$ dalam periode $t$.

PCEO $_{\text {it }}$ : Pemisahan CEO dan komisaris dengan ketentuan 1 = adanya pemisahan antara CEO dan komisaris, dan $0=$ tidak ada pemisahan antara CEO dan komisaris pada emiten $i$ dalam periode $t$.

$b_{1}, b_{2}, b_{3}$ dan $b_{4}=$ koefisien regresi $K_{i t}, U_{i t}, K_{i t}$ dan $\mathrm{PCEO}_{\text {it }}$

Regresi panel memiliki tiga pendekatan yaitu common effect model, fixed effect model dan random effect model. Untuk menentukan mana di antara tiga pendekatan tersebut yang dinilai paling tepat digunakan dalam analisis regresi data panel digunakan Chow test dan Hausman test. Chow test digunakan untuk memutuskan apakah menggunakan model common effect atau fixed effect, sedangkan Hausman test digunakan untuk memutuskan apakah menggunakan model fixed effect atau random effect.

\section{Hasil dan Pembahasan}

\section{A. Pemilihan Model Regresi Panel dan Uji Asumsi} Klasik

Sebagaimana dijelaskan sebelumnya peralatan ekonometrika yang digunakan untuk menganalisis pengaruh empat dimensi $G C G$ terhadap efisiensi perusahaan perbankan adalah regresi panel. Hasil uji chow test memperlihatkan p-value cross section $\mathrm{F}$ sebesar $0,000<0,05$. Dengan demikian dapat 
disimpulkan bahwa berdasarkan uji chow test, model yang dipilih adalah fixed effect model. Selanjutnya uji hausman test menghasilkan p-value cross section random effect sebesar $0,000<0,05$. Hal ini memperkuat alasan bahwa fixed effect model lebih baik bila dibandingkan dengan random effect model.

Alasan menggunakan fixed effect model sebagai model regresi panel terbaik dalam penelitian ini juga didasarkan pada perbandingan grafik residual antara kedua metode seperti terlihat dalam Grafik 1 dan Grafik 2 .

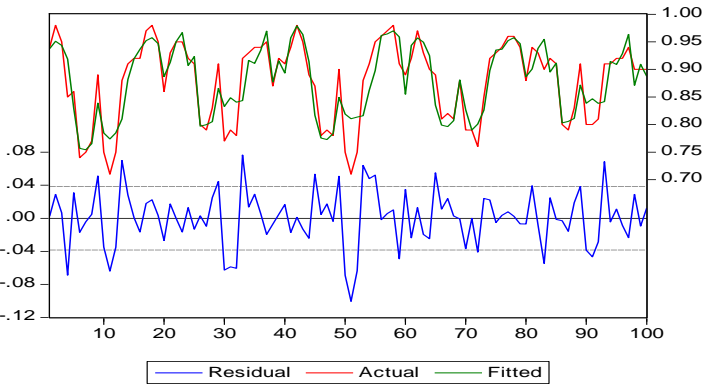

Grafik 1. Residual Metode Fixed Effect Model

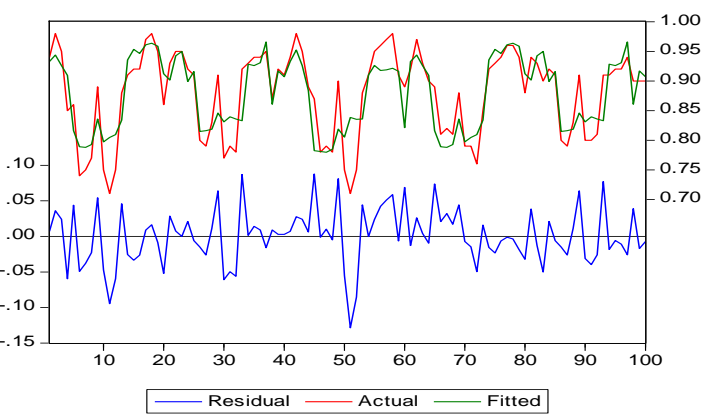

Grafik 2. Residual Metode Random Effect Model

Grafik 1 memperlihatkan residual regresi panel dengan menggunakan pendekatan fixed effect model. Dalam grafik tersebut terlihat bahwa pergerakan atau fluktuasi garis actual relatif dekat dengan fluktuasi garis fitted. Hal ini menerangkan bahwa prediksi pengaruh keempat dimensi GCG terhadap efisiensi perusahaan perbankan relatif akurat. Berbeda halnya dengan metode random effect, seperti ditunjukkan oleh grafik residual (grafik 2) bahwa kendatipun arah kedua garis relatif sama, namun pada observasi tertentu perbedaan antara kedua garis relatif besar. Dengan demikian prediksi yang dihasilkan oleh fixed effect model lebih akurat bila dibandingkan dengan random effect model.

Berdasarkan alasan statistika di atas, maka metode regresi panel yang dipilih dan dibahas dalam kajian ini adalah fixed effect model. Penggunaan model tersebut juga sudah memenuhi ketentuan asumsi klasik yakni residual estimasi terdistribusi secara normal dan tidak terdapat gejala multikolinieritas.

Uji terhadap normalitas residual dilakukan dengan melihat grafik histogram dan normality rest seperti ditunjukkan dalam Grafik 3.

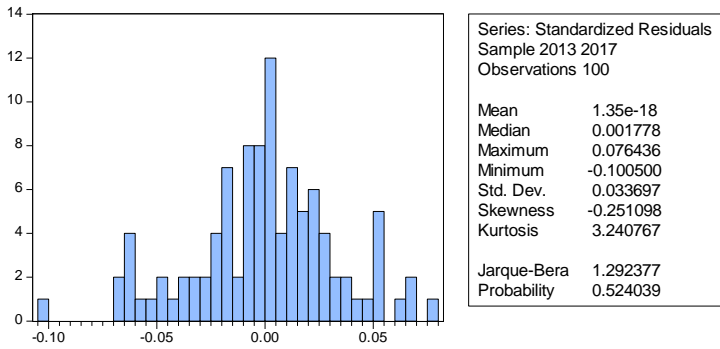

Grafik 3. Normalitas Residual

Grafik 3 di atas memperlihatkan nilai probability sebesar 0,524 lebih besar dari 0,05 dapat diartikan bahwa residual estimasi terdistribusi secara normal.

Selanjutnya gejala multikolinieritas dideteksi dengan cara membandingkan nilai koefisien korelasi antar sesama variabel independen dengan nilai Adjusted $R^{2}$ pada regresi panel. Nilai koefisien korelasi antar dimensi GCG sebagai variabel independen dalam penelitian ini ditunjukkan dalam Tabel 1.

Tabel 1. Koefisien Korelasi Antara Variabel Independen

\begin{tabular}{|c|c|c|c|c|}
\hline & KS & UK & KK & PCEO \\
\hline KS & 1,000 & & & \\
\hline UK & 0,014 & 1,000 & & \\
\hline KK & $-0,019$ & 0,323 & 1,000 & \\
\hline PCEO & 0,167 & 0,731 & 0,446 & 1,000 \\
\hline
\end{tabular}

Sumber: Data Sekunder (Diolah), 2019.

Seluruh nilai koefisien korelasi antar sesama variabel indpenden lebih kecil bila dibandingkan dengan nilai Adjusted- $R^{2}$ pada regresi panel sebesar 0,717. Karena itu dapat disimpulkan bahwa model regresi panel yang digunakan dalam penelitian ini telah terbebas dari gejala multikolinieritas.

\section{B. Hasil Regresi Panel}

Sebagaimana dijelaskan sebelumnya, metode regresi panel yang dianggap paling baik digunakan untuk menganalisis pengaruh keempat dimensi GCG terhadap efisiensi perusahaan perbankan adalah fixed effect model. Model ini juga sudah memenuhi ketentuan bahwa normalitas residual terdistribusi secara normal dan tidak ada gejala multikolinieritas. Hasil regresi tersebut seperti ditunjukkan dalam Tabel 2.

Tabel 2. Hasil Regresi Panel

\begin{tabular}{|c|c|c|c|c|}
\hline Variable & Coefficient & Std. Error & t-Statistic & P-Value \\
\hline $\mathrm{C}$ & 0.904 & 0.057 & 15.840 & 0.001 \\
\hline $\mathrm{KS}$ & 0.274 & 0.066 & 4.171 & 0.001 \\
\hline $\mathrm{UK}$ & -0.008 & 0.009 & -0.868 & 0.388 \\
\hline $\mathrm{KK}$ & -0.161 & 0.051 & -3.170 & 0.002 \\
\hline PCEO & -0.084 & 0.016 & -5.392 & 0.001 \\
\hline
\end{tabular}

Prob $($ F-statistic $)=0,000 ;$ Durbin-Watson stat $=2,114$

Sumber: Data Sekunder (Diolah), 2019. 
Berdasarkan Tabel 1 di atas, maka persamaan regresi panel yang menjelaskan hubungan fungsional antara efisiensi perusahaan perbankan dengan kepemilikan saham, ukuran komisaris, komposisi komisaris dan pemisahan antara CEO komisaris dapat diformulasikan sebagai berikut.

$\mathrm{BOPO}_{\mathrm{it}}=0.904+0.274 \mathrm{KS}_{\text {it }}-0.008 \mathrm{UK}_{\mathrm{it}}-0.161 \mathrm{KK}_{\mathrm{it}}-$ $0.084 \mathrm{PCEO}_{\text {it }}$

Kepemilikan saham berpengaruh positif terhadap rasio BOPO ditunjukkan oleh koefisien estimasi sebesar 0.274 dan $p$-value sebesar 0,001 $(<0,05)$. Sebagaimana dijelaskan sebelumnya, perusahaan dengan rasio BOPO semakin meningkat, mengindikasikan bahwa efisiensi perusahaan tersebut menurun. Karena itu, pengaruh positif kepemilikan saham terhadap BOPO rasio dapat dimaknai bahwa variabel tersebut berpengaruh negatif terhadap efisiensi perusahaan perbankan. Semakin besar persentase kepemilikan saham oleh pihak internal perusahaan, semakin tidak efisiensi pengelolaan perusahaan. Temuan ini bertolak belakang dengan temuan penelitian Perrini et al. (2008) Silva \& Majluf (2008) dan Garcia-Meca \& Sa'nchez-Ballesta (2011) yang menyimpulkan bahwa konsentrasi kepemilikan saham berpengaruh positif terhadap efisiensi perusahaan. Ukuran komisaris tidak berpengaruh terhadap efisiensi perusahaan perbankan. Hal ini ditunjukkan oleh koefisien regresi variabel tersebut terhadap BOPO rasio sebesar -0,008, dan nilai p-value sebesar $0.388(>0,05)$. Jumlah dewan komisaris dalam perusaahan perbankan tidak berpengaruh terhadap efisiensi kegiatan operasional perusahaan tersebut. Perusahaan dengan jumlah komisaris lebih banyak tidak lebih efisiensi kegiatan operasionalnya dibandingkan dengan perusahaan dengan jumlah komisaris lebih sedikit. Temuan ini berbeda dengan hasil penelitian Adnan et al. (2011) yang menemukan bahwa ukuran komisaris berpengaruh positif dan signifikan terhadap efisiensi perusahaan jasa perbankan.

Komposisi komisaris juga berpengaruh positif dan signifikan terhadap efisiensi perusahaan perbankan. Hal ini ditunjukkan oleh nilai koefisien estimasi variabel tersebut terhadap BOPO rasio sebesar -0.161 dan $p$-value sebesar $0,001(<0,05)$. Perusahaan dengan komposisi komisaris independen terhadap total komisaris relatif lebih besar, akan memiliki tingkat efisiensi lebih tinggi dibandingkan dengan perusahaan yang komisaris independennya relatif lebih sedikit. Dengan kata lain, semakin besar persentase komisaris independen dalam suatu perusahaan semakin efisien pengelolaan perusahaan. Hal ini disebabkan, komisaris independen pada umumnya memiliki kepentingan dengan peningkatan kinerja perusahaan dikarenakan hal tersebut terkait dengan sejumlah reward yang akan mereka terima. Karena itu, mereka akan berupaya meningkatkan efisiensi kegiatan operasional perusahaan guna memaksimalkan pendapatan dan laba usaha.

Adanya pengaruh positif komposisi komisaris terhadap efisiensi perusahaan perbankan, mengkonfirmasi hasil penelitian Bozec \& Dia (2005) menyoroti pentingnya komisaris independen dalam upaya memberikan perhatian terhadap pentingnya efisiensi pengelolaan perusahaan. Adanya pengaruh positif komposisi komisaris terhadap efisiensi operasional perusahaan perbankan mendukung temuan penelitian Tanna et al. (2011) yang memberikan bukti empiris bahwa efisiensi perusahaan secara positif dan signifikan dipengaruhi oleh komposisi komisaris pada perusahaan tersebut.

Pemisahan antara CEO dan komisaris juga berpengaruh positif dan signifikan terhadap efisiensi perusahaan perbankan dengan koefisien estimasi variabel tersebut terhadap BOPO ratio sebesar -0.084 dan $p$-value sebesar 0,001 $(<0,05)$. Adanya pemisahan antara jajaran manajemen dengan dewan komisaris berdampak pada peningkatan efisiensi perusahaan perbankan. Hal ini disebabkan eksistensi komisaris independen diharapkan dapat memberikan dampak positif bagi perbaikan pengelolaan perusahaan. Sebagaimana dikemukakan oleh Ehikioya \& Benjami (2009) bahwa pemisahan antara CEO dan dewan komisaris dimaksudkan untuk memastikan kemampuan perusahaan dalam meningkatkan modal tambahan dan mengurangi kesempatan terjadinya korupsi pada perusahaan.

Pengujian signifikansi pengaruh keempat prinsip GCG secara simultan terhadap efisiensi perusahaan didasarkan pada nilai prob (F-statistic). Seperti ditunjukkan dalam tabel 1, hasil pengolahan data memperlihatkan nilai prob (F-statistic) sebesar 0,000 (< 0,05) dapat diartikan secara simultan keempat prinsip GCG (kepemilikan saham, ukuran komisaris, komposisi komisaris dan pemisahan antara CEO \& komisaris) berpengaruh signifikan terhadap efisiensi perusahaan perbankan di BEI.

Tabel 1 juga memperlihatkan nilai koefisien determinasi yang disesuaikan (Adjusted $R^{2}$ ) sebesar 0,717. Artinya, sebesar 71,7 persen BOPO rasio sebagai ukuran efisiensi perusahaan perbankan di BEI dapat dijelaskan oleh keempat prinsip GCG yang digunakan sebagai predictor variable efesiensi tersebut. Sisanya sebesar 28,3 persen lagi dipengaruhi oleh variabel lain. Variabel lain dimaksud adalah semua faktor yang secara teoritis dan empiris dapat mempengaruhi biaya operasional dan pendapatan operasional perusahaan perbankan, seperti suku bunga baik suku bunga simpanan maupun pinjaman/pembiayaan, inflasi dan variabel moneter lainnya yang dapat berdampak pada fungsi intermediasi keuangan yang dilakukan oleh perbankan.

\section{Kesimpulan}

Efisiensi kegiatan operasional sangat penting artinya bagi peningkatan kinerja perusahaan perbankan. Implementasi GCG pada perusahaan tersebut diharapkan mampu mendorong terwujudnya efisiensi operasional dan pada gilirannya berdampak pada peningkatan pendapatan dan laba perusahaan. Penelitian ini menyimpulkan bahwa tidak semua prinsip GCG 
berdampak pada peningkatan efisiensi perusahaan perbankan yang listing di BEI. Konsentrasi kepemilikan saham oleh pihak internal perusahaan secara nyata berdampak pada penurunan efisiensi perusahaan tersebut. Semakin besar persentase kepemilikan saham oleh pihak internal perusahaan semakin rendah tingkat efisiensi.

Ukuran komisaris mempengaruhi efisiensi perusahaan perbankan. Perusahaan dengan jumlah komisaris relatif lebih banyak tidak memiliki tingkat efisiensi yang lebih baik atau lebih buruk dibandingkan dengan perusahaan yang memiliki komisaris lebih sedikit. Hal ini mengindikasikan bahwa intervensi kebijakan yang dilakukan oleh manajemen dalam mendorong efisiensi kegiatan operasional perbankan tidak tergantung pada ukuran dewan komisaris.

Komposisi komisaris dan pemisahan antara CEO dan komisaris berpengaruh positif dan signifikan terhadap efisiensi perusahaan perbankan. Adanya komisaris independen dalam suatu perusahaan dapat mendorong peningkatan efisiensi operasional dan pada akhirnya berdampak pada kinerja keuangan perusahaan. Demikian pula halnya dengan pemisahan antara komisaris dan CEO juga dapat meningkatkan efisiensi pengelolaan perusahaan.

Mengacu pada kesimpulan di atas, maka yang menjadi rekomendasi penelitian ini sebagai berikut.

a. Sebaiknya kepemilikan saham perusahaan perbankan di BEI lebih berorientasi pada pelibatan publik secara umum. Artinya, perusahaan perbankan tersebut harus lebih mengutamakan kepemilikan sahamnya oleh masyarakat umum.

b. Keberadaan komisaris independen merupakan kebutuhan bagi perusahaan perbankan guna meningkatkan efisiensi operasional perusahaan tersebut. Karena itu, setiap perusahaan perbankan sebaiknya meningkatkan jumlah komisaris independen dalam perusahaan tersebut.

c. Guna meningkatkan efisiensi operasional perusahaan perbankan, diperlukan adanya pemisahan antara CEO dan komisaris. Sehingga seseseorang anggota komisaris dapat melaksanakan tugasnya secara baik dalam hubungannya dengan pelaksanaan tugas oleh mereka yang bekerja sebagai CEO. Rangkap posisi antara komisaris dan CEO akan berdampak buruk pada pengelolaan perusahaan sehingga dapat mempengaruhi efisiensi kegiatan operasional.

d. Bagi peneliti yang tertarik untuk mengkaji keterkaitan antara implementasi GCG dengan efisiensi perusahaan perbankan, sebaiknya memasukkan dimensi GCG lainnya sebagai predictor variable bagi efisiensi. Dimensi tersebut misalnya, fairness, transparancy, accountability dan dimensi lainnya. Sehingga dapat diperoleh informasi mengenai pengaruh masing-masing dimensi tersebut terhadap efisiensi operasional perusahaan secara lebih detail.

\section{Ucapan Terima Kasih}

Kami sebagai peneliti mengucapkan terima kasih yang sebesar-besarnya kepada Ditjen Penguatan Riset dan Pengembangan Kementerian Riset, Teknologi dan Pendidikan Tinggi sebagai penyandang dana penelitian pada skema Penelitian Dosen Pemula (PDP) tahun 2019, dan tidak lupa pula kepada LP2M Sekolah Tinggi Ilmu Ekonomi (STIE) Sabang, Banda Aceh yang telah ikut menfasilitasi kelancaran proses penelitian ini.

\section{Daftar Pustaka}

Adams, R., \& Mehran, H. 2003. Is corporate governance different for bank holding companies? Economic Policy Review, 9(1), 123-142.

Adnan, M. A., S. N. N. Htay., H. M. A. Rashid dan Ahamed K. M. M. 2011. A Panel Data Analysis on the Relationship between Corporate Governance and Bank Efficiency, Journal of Accounting, Finance and Economics, 1(1); 1-15.

Amri, K., \& Nazamuddin. 2018. Is there causality relationship between economic growth and income inequality? Panel data evidence from Indonesia, Eurasian Journal of Economics and Finance, 6 (2), 8-20.

Amri, K., Qurratul'aini, I., \& Julianty. 2018. Preferensi Nasabah Memilih Produk Pembiayaan Bank Aceh Syariah di Kota Banda Aceh, Jurnal Samudra Ekonomi dan Bisnis 9(1), 31-41.

Bebeji, A., Mohammed, A., \& Tanko, M. 2015. The effect of board size and composition on the financial performance of banks in Nigeria, African Journal of Business Management, 9(16), 590-598.

Beiner, S., W. Drobetz, F. Schmid \& Zimmermann, H. 2003. Is Board Size an Independent Corporate Governance Mechanism. http://www.wwz.unibas.ch /cofi/publications/ papers/2003/06.03.pdf.

Boone, N., Colombage, S., \& Gunasekarage, A. 2011. Block shareholder identity and firm performance in New Zealand. Pacific Accounting Review, 23(2), 185-210.

Bozec, R., \& Dia, M. 2005. Board structure and firm technical efficiency: Evidence from Canadian stateowned enterprises, Pacific-Basic Finance Journal,13(4), 635-651.

Ceha, R. 2000. Pengembangan Data Envelopment Analysis (DEA) untuk Pengukuran Prestasi Karyawan (Individual) dalam Team Kerja, Jurnal TMI, 1(1), 1-21.

Choe, H \& Lee, BS. 2003. Korean bank governance reform after the Asian financial crisis, PacificBasic Finance Journal, 11(4), 483-508.

Dalton, Dan R., \& Chaterine M. Dalton. 2006. Spotlight on Corporate Governance. Business Horizons Indiana University, 49, 91-95.

Ehikioya, B. I. 2009. Corporate governance structure and firm performance in developing economies: evidence from Nigeria. Journal of Corporate Governance, 9(3), 231-243.

Garcia-Meca, E., \& Sa'nchez-Ballesta, J. P. 2011. Firm value and ownership structure in the Spanish 
capital market. Corporate Governance, 11(1), 4153.

Jiang, H., Habib, A., \& Smallman, C. 2009. The effect of ownership concentration on CEO compensationfirm performance relationship in New Zealand. Pacific Accounting Review, 21(2), 104-131.

Klein, A. 2008. Firm performance and board committee structure. Journal of Law and Economics, 41, 137165 .

Krivogorsky, V. (2006). Ownership, board structure, and performance in continental Europe, The International Journal of Accounting, 41(2), 176197.

Laeven, L. 2009. Risk and Efficiency in East Asian Banks, Financial Sector Strategy and Policy, The World Bank Working Paper.

Perrini, F., Rossi, G., \& Rovetta, B. 2008. Does ownership structure affect performance? Evidence from the Italian market. Corporate Governance: An International Review, 16(4), 312-325.

Rebeiz, K. S., \& Salameh, Z. 2006. Relationship between governance structure and financial performance in construction, Journal of Management in Engineering, 22(1), 20-26.

Silva, F., \& Majluf, N. 2008. Does family ownership shape performance outcomes. Journal of Business Research, 61, 609-614.

Tanna, S., Pasiouras, F., \& Nnadi, M. 2011. The effect of board size and composition on the efficiency of UK banks. International Journal of the Economics of Business, 18(3), 441-462

Weir, C., David. L., \& McKnight, P. J. 2000. An Empirical Analysis of The Impact ofCorporate Governance Mechanisms on The Performance of UK Firm. http://papers.ssrn.com/sol3/papers.cfm?

Wijayanto, A. 2010. Kinerja Efisiensi Fungsi Intermediasi Bank Persero di Indonesia dengan Menggunakan Data Envelopment Analysis (DEA), Jurnal Keuangan dan Perbankan, 14(1), 110-121. 